\title{
Case study on how Double Lid (DL) Silos improve grain storage among farmers in semi-arid area by $\mathbf{1 0 0 \%}$
}

\author{
Isaac Muringih- Researcher Developer \\ P.O. Box 58032 - 00200; Nairobi Kenya. \\ Case Study Food Technology (Food storage and Distribution)
}

\begin{abstract}
The use of Double Lid (DL) silos in grain storage lead to one hundred per cent prevention of grains from being infested by weevils or destruction from rodents. The structures are economically viable and cheap in management compared to other forms of food storage that has been in use over the years. The technology of putting up the structures is locally available and easy to assimilate by the beneficiaries. The results of this study indicated that DL silos completely deter any form of grain destruction, it provides security; boost the income of the farmer through reduction of exploitation by grain merchants. The silos can hold large quantity of grains and they do not require use of chemical application at the time of storage. The findings of the study indicated that if farmers can have DL silos, each family can improve their living standards by $40 \%$ because the system is $100 \%$ better and usable. Exhausting oxygen from the DL silo before sealing and using desiccant material to arrest any possible moisture that may build inside the silo after sealing are the key secrets of keeping the grains clean. Further, constructing the structure under a roof to keep it at normal room temperature minimises building of moisture in the stored grains resulting from high heat from direct sun. The study proved that weevils cannot with stand lack of oxygen in properly sealed silos. Further, farmers can change their lifestyle if they can store their grains in DL Silos.
\end{abstract}

\section{Introduction:}

The article is an original case study I conducted between October 2011 and September 2012 on the use of Double Lid silos in storage of grains in semi-arid regions of Kenya. The study involved participatory actions with selected farmers in Thura River Basin which is in Mbeere central region in Embu County in Kenya. The basin is semi-arid area characterised with low rainfall and experiencing two rainy seasons with short one starting in November to December and the long one starting from March to May. Due to climatic changes facing many parts of Africa, farmers have expressed their fear of being able to adapt to the changing climate without addressing some of the common problems they face in farming. In general the farmers appreciate various technologies introduced or suggested to them in order to increase their food production but their main concern is lack of food sustainability due to poor storage systems or high cost storage techniques proposed to them. Double Lid (DL) silo technology was presented to 23 farmers in the Thura River Basin and as team went through various stages of implementing the idea. Seven DL silos were constructed and their performance was determined at different stages of use. While there are other cross-cutting issues such as quality of seeds, plant husbandry and weeding that contribute to grain production. This study limited itself on the problem of storage of grains after harvesting.

\section{Objectives of the case study:}

The objective of this case study was to determine the suitability of Double Lid ferrocement constructed silos for grain storage in semi-arid regions in Kenya. Problem: The problem which I was addressing was the high level grain loss which occurs after harvesting among the farmers. The problem of grain loss continues to be the most discouraging factor to farmers with small farms or without ability to work on large farms. The problem occurs in three ways: a) losses incurred out of infesting by weevils which lead to destruction of grains stored in sacks or in the open; b) losses that occur from possible theft of stored grains in unsecured homesteads; and c) high exploitation by grain merchants after harvesting of grains and threshing before storage. The latter mostly occur due to lack of storage place or cost and fear of the grains losing value if they get infested with weevils. Therefore, the problem which was be addressed was how best can the farmers store their grains in a secure way, without the pressure of disposing them and without the danger of losing them to weevils or rodents.

\section{Implementation:}

The case study was conducted taking the form of an action research where I selected and work throughout with a team of 23 farmers for a period of 11 months. Every action was intended towards solving the problem of grain storage by the farmers. The study started with selecting the 23 farmers out of 51 farmers living in Thura 
River Basin. The 23 farmers were selected based on their willingness to participate, secondly, being able to grow more than 1 tonne of grains per season, thirdly, and the ability to learn and to act as per the learning. The learning of how the DL silo works theoretically was conducted for four Saturdays. I spent another three months collecting the grain production for the seasons 2011 Nov - December, March - May 2012. Later the record for Nov - December 2012 was collected in March 2013. Table 1 below illustrates the composition of the 23 participants in the case study.

\begin{tabular}{|c|c|c|c|c|c|c|c|c|c|}
\hline \multirow{2}{*}{ Gender } & \multirow[b]{2}{*}{ Number } & \multicolumn{4}{|c|}{ Participants age distribution } & \multirow[b]{2}{*}{$\begin{array}{l}\text { Average } \\
\text { Land size }\end{array}$} & \multirow[b]{2}{*}{$\begin{array}{l}\text { Grains in } \\
\text { tonnes }\end{array}$} & \multirow[b]{2}{*}{$\begin{array}{l}\text { Average } \\
\text { Education }\end{array}$} & \multirow[b]{2}{*}{$\begin{array}{l}\text { Average } \\
\text { number } \\
\text { Dependants }\end{array}$} \\
\hline & & $30-40$ & 41-50 & $51-60$ & $61>$ & & & & \\
\hline Men & 14 & 5 & 3 & 6 & -- & $2 \mathrm{Ha}$ & 1.5tonnes & Class 7 & 7 \\
\hline Women & 9 & 2 & 3 & 3 & 1 & $1.5 \mathrm{Ha}$ & $3 / 4$ tonne & Class 6 & 8 \\
\hline Totals & 23 & 7 & 6 & 9 & 1 & $1.75 \mathrm{Ha}$ & 1.12tonnes & Class 7 & 8 \\
\hline
\end{tabular}

Table 1: The composition of the participants

The farmers over the years have been farming grains such as maize, beans, cow peas, pigeon peas, sorghum and millet. Other grains such as finger millet are not produced in large quantity. According to the participants the average production on the six major grains in three seasons 2011 Nov. - December season, 2012 March -May season and 2012 Nov.- December season was represented as shown in the table 2 below.

\begin{tabular}{|l|l|l|l|l|l|l|l|}
\hline Gender & Number & $\begin{array}{l}\text { Maize } \\
\text { (tonnes) }\end{array}$ & $\begin{array}{l}\text { Beans } \\
\text { (tonnes) }\end{array}$ & $\begin{array}{l}\text { Cow peas } \\
\text { (tonnes) }\end{array}$ & $\begin{array}{l}\text { Pigeon peas } \\
\text { (tonnes) }\end{array}$ & $\begin{array}{l}\text { Sorghum } \\
\text { (tonnes) }\end{array}$ & $\begin{array}{l}\text { Millet } \\
\text { (tonnes) }\end{array}$ \\
\hline Men & 23 & 8 & 4 & 9 & 9.5 & 7 & 2 \\
\hline Women & 9 & 4 & 2.5 & 5 & 6 & 8 & \\
\hline Totals & $\mathbf{2 3}$ & $\mathbf{1 2}$ & $\mathbf{6 . 5}$ & $\mathbf{1 4}$ & $\mathbf{1 5 . 5}$ & $\mathbf{1 5}$ & 3 \\
\hline
\end{tabular}

Table 2: The average production of the six major grains in three seasons

Before construction of the DL silos the farmers' storage on average for different grains for the 23 farmers after the harvest is as shown on table 3 below. The period of storage after harvesting did not exceed three months.

\begin{tabular}{|l|l|l|l|l|l|l|l|}
\hline Gender & Number & $\begin{array}{l}\text { Maize } \\
\text { (tonnes) }\end{array}$ & $\begin{array}{l}\text { Beans } \\
\text { (tonnes) }\end{array}$ & $\begin{array}{l}\text { Cow peas } \\
\text { (tonnes) }\end{array}$ & $\begin{array}{l}\text { Pigeon peas } \\
\text { (tonnes) }\end{array}$ & $\begin{array}{l}\text { Sorghum } \\
\text { (tonnes) }\end{array}$ & $\begin{array}{l}\text { Millet } \\
\text { (tonnes) }\end{array}$ \\
\hline Men & 23 & 1.5 & 1.2 & 3 & 3.5 & 3 & 1 \\
\hline Women & 9 & 0.75 & 1.5 & 1.5 & 2.6 & 3.8 & 2.3 \\
\hline Totals & $\mathbf{2 3}$ & $\mathbf{2 . 2 5}$ & $\mathbf{2 . 7}$ & $\mathbf{4 . 5}$ & $\mathbf{6 . 1}$ & $\mathbf{6 . 8}$ & $\mathbf{3 . 3}$ \\
\hline
\end{tabular}

Table 3: Average quantity of grains stored for more than three months

Construction of DL Silos: Due to time and finances seven DL silos were proposed in seven homesteads. Three silos were constructed on the homestead of women participants. The structures were constructed within a period of two months from January 2013 to March 2013. Each of the DL silo was divided into four chambers of equal size. The seven farmers after drying their grains traditionally out in the hot sun they prepared the grains for storage in the DL silos. However, in one of the meeting it was agreed that the most weevil prone grains should be targeted first. These included maize, beans, cow peas and pigeon peas should be stored in order to determine the effectiveness of the DL silo.

Specifications: This invention has certain specifications which had to be understood by the participants before embarking on the construction and this was the essence of conducting the one month training in the beginning of the study. The specification make the DL silo unique compared to other similar structures that might have been used in grain storage. Such comprises of;

$>$ Ferrocement impermeable wall constructed using cement, steel bars and sand.

$>$ Desiccant chamber attached on the inner top side of the silo (structure) accessed direct through an air tight lid. The desiccant is supported by gauze wire base that allows absolve any moisture from the grains stored in the silo.

$>$ Candle tray on the inner top side that hold the candle lit after filling the silo to exhaust oxygen before sealing the silo.

$>$ Slanting angled bottom to allow easy sliding of grains during emptying of grains inside the silo.

$>$ Two air tight lids on the top - one leading to the desiccant chamber and the other leading to the silo hallow.

The use of ferrocement structure in the construction is to build an enclosure for storing dried food grains and to prevent ingress of oxygen. The structure allows no oxygen to the stored grains. The insect that may be present will not survive due to lack of oxygen. The walls are constructed using steel bars and filled and plastered with a mixture of sand and cement at acceptable ratio. The structure is circular in cross-section as the preferable shape for easy grain holding and stability.

This allows the bottom shape to be slanting to allow grains slides easily when emptying the silo. The outside is preferably smooth and painted white to reduce absorption of heat at any given time. The size of the silo can differ depending to the amount intended to be stored. Also individual families can easily construct and maintain their own silo which is extremely economical and security solution. The height and widths are designed to allow easy operation of the silo, and taking into consideration the climatic conditions of the place the silo is constructed. Both extremes in climate must be avoided to get the right results in this storage solution. 
Before grains are stored they are dried to at least $13 \%$ moisture content, and in case of moisture building inside the silo, the desiccant will absolve it reduce any possible building of moulds inside the silo.

Candle tray on the inner top side is instrument in assisting in reducing oxygen in the silo after filling it with the grains. Use of the candle to reduce oxygen is a genuine way of allowing the silo to be opened many times without the danger of making any pest thrive in the silo. The candle is lit every time before sealing the inlet because it only goes off after exhausting the oxygen inside the silo.

The tray holds any possible residue from the candle. A red burning charcoal can also play the same role if carefully placed on the tray and allowed to continue burning for 2-3 minutes depending with the space left after filling the grains. The purpose is to get rid of oxygen from the silo.

Slanting angled bottom simply allows gravity release of the stored grain to the outlet which is set at the bottom of the silo. The angling of the base is necessary as the collection of the grains is made simple and the new technology can be used in any setting.

The outlet lid is a doubled leveled seal with an inner flap to opens when the air tight lid is opened. The flap is fitted with a rubber gasket which completely reduces the chances of air going through the outlet to the grains.

Preferred sealing of the inlet is the air-tight lid, where tire tubes can be used as gaskets. The possibility of reducing cost on the structure is achieved when such simple but scientific approach is used. Round the lid, the placing is made to hold tightly, with no possible inlet of air into the silo. The other lid also tightly sealed leads to the desiccant chamber.

This second inlet only allows the desiccant to be inserted though the base is constructed of gauze wire allowing the desiccant to absolve any moisture that may be generated from the grains if they had not been dried according to the accepted moisture content standards.

The loading gear make loading of grains into the silo easier after drying them under solar driers. The gear is detachable from the silo and only mounted when grains are being emptied in the silo. The illustration given in the first diagram shows the complete faction of system under an ideal condition. However, grains can be emptied in the silo manually without using the loading gear.

Below I have presented a diagram (Diagram 1.) showing the main features as explained above.

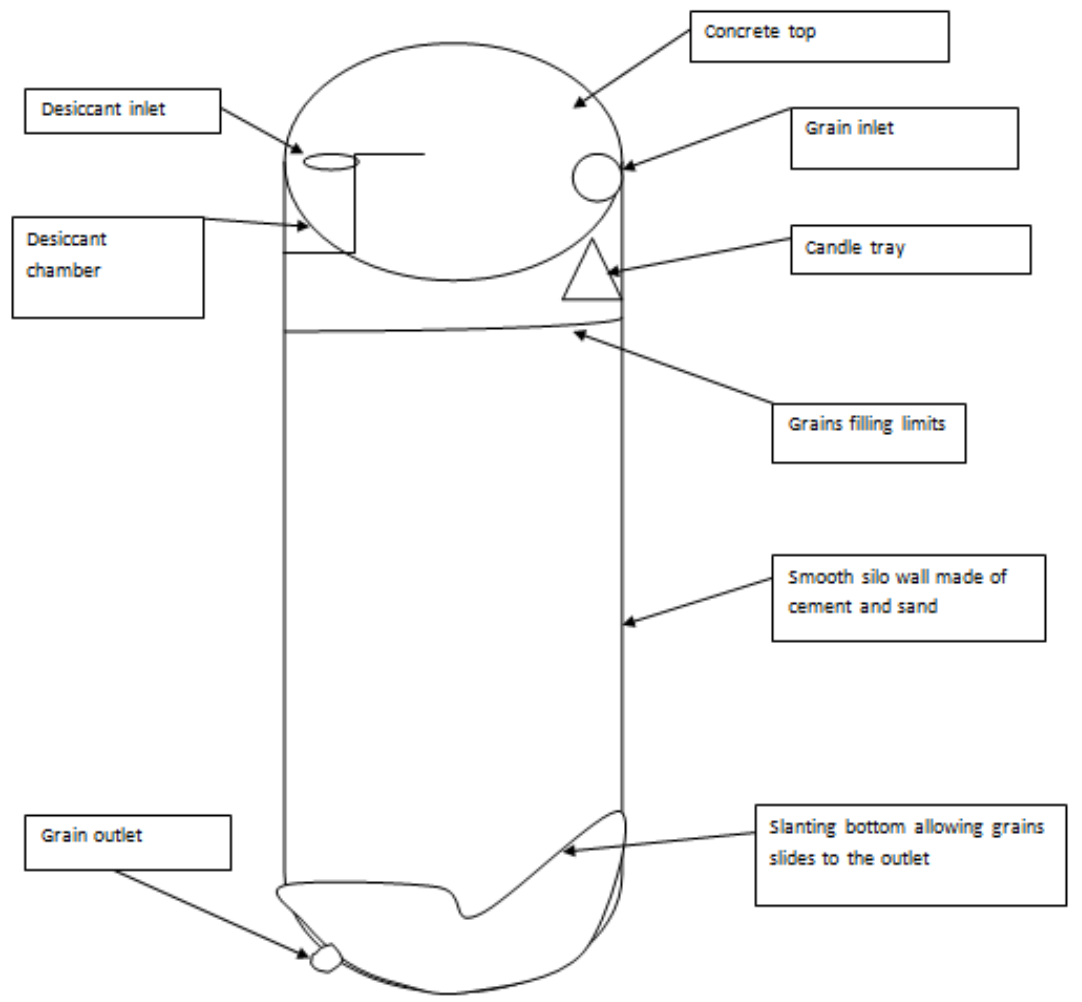

DL-Grain Storage Silo

Diagram -1: Features of a Double Lid Silo

Grain storage statistics based on types -table and figures

The table 4 below illustrates the storage of grains in each of the seven silos constructed. The grains stored were maize, beans, cow peas, and pigeon peas. The compartment of each silo was filled with 500 kilos of grains. The 
total grain held in one silo estimated at 2 tonnes. This quantity was agreed show that the results can be verified with a period of three months. Each silo was given a code number according to where it is and time of construction. Two compartments of silo S/Ta2/2013 were filled with beans and pigeon peas grains and 50 weevils were added in each compartment. One compartment of S/Va3/2013 was filled with maize grains already infested and lavas and adults were alive and another compartment was filled with infested cow peas where adults and lavas were alive. One compartment of Silo S/Ka5/2013 was filled with maize grains and 100 weevils were added and another pigeon peas and more weevils added in before sealing; and two compartments of silo S/La6/2013 were filled with cow peas and beans and in each of the compartment weevils of unknown number were added before sealing the silo.

\begin{tabular}{|l|l|l|l|l|l|l|l|l|}
\hline Silo Code & $\begin{array}{l}\text { Maize } \\
\text { (kgs) }\end{array}$ & $\begin{array}{l}\text { Weevils } \\
\text { added }\end{array}$ & $\begin{array}{l}\text { Beans } \\
\text { (Kgs) }\end{array}$ & $\begin{array}{l}\text { Weevils } \\
\text { added }\end{array}$ & $\begin{array}{l}\text { Cow Peas } \\
\text { (Kgs) }\end{array}$ & $\begin{array}{l}\text { Weevils } \\
\text { added }\end{array}$ & $\begin{array}{l}\text { Pigeon } \\
\text { Peas (Kgs) }\end{array}$ & $\begin{array}{l}\text { Weevils } \\
\text { added }\end{array}$ \\
\hline S/Pa1/2013 & 500 & --- & 500 & --- & 500 & ---- & 500 \\
\hline S/Ta2/2013 & 500 & ----- & 500 & $<50$ & 500 & ----- & 500 \\
\hline S/Va3/2013 & 180 & $\begin{array}{l}\text { Already } \\
\text { infested }\end{array}$ & 500 & ---- & 100 & $\begin{array}{l}\text { Already } \\
\text { infested }\end{array}$ & 500 \\
\hline S/Fa4/2013 & 500 & ------ & 500 & ----- & 500 & ------ & 500 \\
\hline S/Ka5/2013 & 500 & $<100$ & 500 & ---- & 500 & ---- & 500 \\
\hline S/La6/2013 & 500 & ------- & 500 & $>100$ & 500 & $>100$ & 500 \\
\hline S/Ha7/2013 & 500 & ----- & 500 & ---- & 500 & ---- & - \\
\hline
\end{tabular}

Table 4: Storage and weevils added

The grains stored in the DL silos were held for a period of three month before they were drained from the compartments. The outcome of the test was that all the grains with weevils added, did not show any attempt of destruction and all the weevils came out dead. The silo S/Va3/2013 which the two compartments had been filled with already infested grains both maize and cow peas the result was that, the grains that went in without any hallow, no sign of destruction was evident. Further, the lava that was in the infested seeds at the time of sealing the silo, didn't mature and indications was that they died before. The same was the case with the adult weevils which showed that they died immediately after the oxygen which was in the silo was exhausted by the burning candle. The same results were gotten for the silos which had the weevils introduced at the time of sealing. None of the insect survived neither none of the weevils was found to had any attempt to destroy the seeds for the three months grains were stored.

In the other silos where grains were cleaned and filled in the compartments, after three months they were checked and no sign of destruction was seen. This led to my substantive conclusion that if seeds are careful dried, cleaned and stored in DL silo which is tightly sealed after exhausting the oxygen using the candle, the farmer will be able to hold his or her grains for as long as he or she want to use them. Secondly, the desiccant on the second inlet equally controlled any possible building of moisture in the silo thus keeping the grain moisture content at the level it had dried. According to the results after conducting this study, I can argue that DL silos are the most ideal structures for holding grains by small and medium farmers in regions of food shortage especially semi-arid areas of Kenya. The DL are extremely effective in holding grains for long period, high quality, increases house income; contribute to improved nutrition status, income improved.

In this case study the DL silo was found to be highly valuable compared to other forms of grain storage used or recommended to farmers in semi-arid regions of Kenya. Farmers who would invest in DL silos can reap greater benefit compared to other who constructs grain stores. The reason for this argument was proved in this case study when grain loss was compared between farmers who used the DL silo and those who traditionally used the agricultural backed grain stores. The farmers using stores had cost on storage sacks which was estimated to be KES 150 per empty sack that can carry 90 kilograms of grains. Secondly, the chemicals required ranged between KES 2,000 and 3,000 for the farmer with 10 bags of maize in every five months. Thirdly, where the application of the chemical lasted for over a season, it was found out that the grains lost their market value with $60 \%$. Meaning if the grains stored without chemical of last season would cost KES 200 per kilo, the grains stored under chemicals were costing KES 120 and the farmers reported that the price would be offered if there availability of grains stored without chemicals would not be available. Another investment return of using DL silo is that, when the few farmers adopted DL silo grain storage method; they influenced the market price because the grain merchants and middle men lack grains and to remain in business, they negotiated better prices with farmers who still held their clean grains in their silos. This happened after those using the ordinary grain stores selling their grains to avoid losses or expiry of the chemicals.

The farmers involved in this case study and who constructed DL silos, increased their grain production in the following season 2012-2013 with 120\%. Meaning, out of the 7 farmers with DL silos, each was able to increase their harvest with double. Increase was more in maize grains, beans and cow peas. Another factor was increase in food surplus for marketing, where the seven farmers maintained a high margin of KES 80 per kilo of maize compared to others farmers who had sold their maize grains between the range of KES 20 and 40 after the harvest and the close of the season. 


\section{Usefulness of technology:}

DL storage facility is a wonderful technology and friendly to the farmers. As noted earlier in the illustration of the DL silo functions, constructing the DL silo is just a fan to the farmers; the reason being that when I conducted the study, part of the activity was to train the farmers on how to construct the DL silos of all sizes. It was found out that silos measuring 3 meters diameter and 4 meters height were more favoured because they hold large volumes of grains and they are easy to manage. This size of silo when building the farmer would use one roll of chain-link, four bars of Y-10, 10 kilograms of biding wire, and five bags of cement. The cost ranged between KES 10,000 and 13,000. The unskilled labour is the most needed because the artisan is only needed to guide the owner on taking the measurement in one day. The rest the farmer and the friends can do without many problems. The artisan can be visiting so that he can guide on how to work on the top part of the silo where there two man-holes, candle tray, and desiccant holder. The cost of constructing the silos is lower that constructing grain stores which according to the farmers who attempted to construct grain stores following ministry of agriculture specifications, the cost ran into above KES 40,000 which is enough to construct two huge silos of 20 tonnes of grains. The high cost is because the number of iron sheets, wood for roofing, nails, cement, ballast and stones are all costly due to transport to the site. Many of the families have very poor access roads and majority using just paths to their home stead.

DL silo construction involves simple available resources which the farmer can easily get without purchasing. According to the form of the structure it is a ferro-cement constructed where sand mixed with cement and pasted on the firmly held chain-link wire until it forms a certain thickness of wall. The inside is plastered to give it the smooth surface needed

Double Lid Silos are highly useful as far as grain storage is concerned in rural communities whose lifeline is agricultural related. DL silos solves three major pressing problems in the household and in the community namely, security, losses and exploitation. In each of these problems they contribute to grain drain in 30 to 40 percent loss incurred by the farmers after harvest.

Security of the stored grains is of big concern to all farmers. $87 \%$ of the farmers reported that their granaries can be accessed easily by thieves if they know there homestead is not secured day and night. This was the basis of some farmers opting to store their sacks of grains in their living rooms and bedrooms; though the chemicals they apply on the grains could be smelled. Out of the farmers who fail to secure their grains led to losses. During the period of six months in my case study 9 percent of the farmers during the season lost 60 percent of their grains through theft and fire either set on the granaries by someone intentionally and it was a growing concern to the farmers. The number of lives that suffered after the theft or fire on the granaries represented $23 \%$ of the community population within the research catchment area. The number aggravated the problem of food poor in that year which we recorded at $42 \%$ of the total population.

The problem of grain loss through bowl-weevils and other rodents is another which the DL silo brings down to below $2 \%$. In my findings proper training, construction and management of the silo led to zero loss of grains compared to storage using chemicals which still had $11 \%$ loss of grains after harvesting. In the latter grain losses occurred because rats continued to attack the sacks and destroy the grains though they had chemical applied on them. $73 \%$ of the farmers reported that grains particularly maize was attacked by weevils right on the farms. The problem as it was noted in my assessment was that birds contributed to weevil infesting the drying combs because of opening them during maturity. Certain maize varieties were more susceptible to birds compared to others. These includes varies that formed grains to the top of the combs. After the birds open the top part of the comb to access the milky grains, though the farms scares the birds, $80 \%$ of the opened combs during the harvest, the farms reported seeing weevils. The farmers use traditional methods of drying grains spread on rocks of canvas or traditionally made dryers similar to the one seen in the photo. According to my assessment and interaction with the farmers they do little to deter the weevils sighted in the grains, but they said weevils either die during drying of the grains on the sun. However, some farmers $17 \%$ were able to identify life weevils even after drying of the grains on the sun for two weeks. But when the grains were stored in DL silo and the due process of sealing was followed, after the grains were empted after two months the weevils which went in with dried grains came out dead and none of the grain had any hallow on it and they came out clean as they went in.

The problem of farmer exploitation through the use of DL silos will be checked and the business will be left between willing seller and willing buyer because the farmers will only sell their grain when the market is favourable to them. Fear of losing the grains after harvesting is a factor that led farmers to sell their grains at throw away prices to avoid a situation of having the grains lost through weevils and rodents. Equally, many of the farmers $(56 \%)$ reported that use of chemicals which they are not trained on or knowledgeable about caused health problem. The DL silo eliminates the worries and the fears of the farmers by providing them with confidence to hold up until the market for the grain promises higher profits. Compared to chemical use on grains as storage method, DL silos are far much economical and environmentally appropriate considering that the farmer after following the few simple steps of storing the grains in the silo he or she has nothing else to worry. 
The farmer only drains few kilograms of grains that is needed for a week and which they are sure it will not get wasted because of exposing for long time. Health-wise grains stored in DL silos do not require washing because they are ever clean and naturally stored.

In essence DL silo storage method adds value to the work of the farmers and it can easily contribute to food sustainability in a community. Further, it increases business concept because farmers are able to determine the amount of food they can use and surplus they can use to enter the market with better prices. Grain loss has stood on the way of farmer food production and this method can lead to farmers boosting grain production which will be a very positive factor.

\section{Conclusion:}

This article emphasise the importance of farmers improving their grain storage taking into considerations the many challenges resulting from climate change. A part from increasing their production, farmers have a reason of improving storage of grains in order to gain more income from their grains. Further, for them to be able to negotiate the prices of grains with grain merchants, they need to have secure, quality grains which can get better prices at all times. The construction of DL silos is necessary to fast track agricultural development in semi-arid areas and to enable such regions which are currently considered food poor, to be self sustaining in terms of food. DL silos are far suitable and manageable by all classes of people and it is my strong recommendation that storage of grains be improved by construction of DL silos at household level and at village level.

\section{References}

[1]. Bationo, et al. 2012. Lessons learned from long-term soil fertility management experiments in Africa. Springer Dordrecht. New York.

[2]. Gomez, M.I. 1981. Effects of drying on the Nutritive value of Foods in Kenya: Process Of food drying workshop. Edmonton, Alberta, Canada.

[3]. Kanga'ra, Sutherland \& Gethi; 1997 (eds). Proceedings of the conference on participatory Dryland Agricultural Research east of Mount Kenya. January 21-24, 1997 KARI. Kitale. Kenya.

[4]. Micheni, Kariuki, Gethi \& Rees. 1999 (eds). Participatory Rural appraisals of the farming systems of eastern Kenya 1998. KARI. Kitale. Kenya

[5]. Mosse, J.C. 1993. Half the world, Half a change. Oxfam. Oxford

[6]. Opuka, E.H. 2006. Participatory learning and action (PLA). Zapf Chancery. Eldoret Kenya.

[7]. Orr, D.W. 1992. Ecological Literacy Education and the transition to Postmodern world. State University of New York. New York.

[8]. Price \& Meitzner. 1996. Amaranth to Zai Holes: Ideas for growing food under difficult conditions. ECHO. North Fort Myres. Florida.

[9]. Soule \& Piper. 1992. Farmining in nature's image: An Ecological approach to agriculture. Island Press. Washington D.C.

[10]. Sutherland, Ouma \& Ndubi (eds) 1995. Farming in Mbeere: Report of an informal diagnostic survey of a farming system of lower Embu, Kenya. KARI Regional Research Centre, Embu.

[11]. Wallace \& March. 1991. Changing perceptions. Oxfam. Oxford.

[12]. WHO, 1979. The Health aspects of food and nutrition. ( $3^{\text {rd }}$ edition). WHO. Manila 